\title{
Shaping activation policy at the street level : Governing inactivity in youth employment services
}

\section{Haikkola, Lotta}

2019-08

Haikkola , L 2019 , ' Shaping activation policy at the street level : Governing inactivity in youth employment services ' , Acta Sociologica , vol. 62 , no. 3 , pp. 334-348 . https://doi.org/10.1177/000169931878

http://hdl.handle.net/10138/308611

https://doi.org/10.1177/0001699318784341

unspecified

acceptedVersion

Downloaded from Helda, University of Helsinki institutional repository.

This is an electronic reprint of the original article.

This reprint may differ from the original in pagination and typographic detail.

Please cite the original version. 


\title{
Author's Accepted Manuscript
}

\section{Shaping activation policy at the street level: Governing inactivity in youth employment services}

\begin{abstract}
Activation policies form the core of employment policies in most OECD countries. They are part of 'active' welfare states and associated neoliberal forms of governance that seek to govern through freedom by producing self-governing and responsible subjectivities. This article uses ethnographies of governmentalities to examine if and how such subjectivities are put in practice in street-level encounters in local welfare delivery. Based on an ethnographic research of youth services in the Public Employment Services (PES) in Helsinki, Finland, the article shows that despite the policy focus on active citizenship, the street-level practice entails not only liberal ideas of self-governing individuals but also authoritarian measures. What is governed in the meetings is not the young people's selves but their time and behaviour. In the process, the notion of active citizenship is emptied and transformed to mean participation in supervised activities offered by the PES. Such practice also reworks the temporal structures and creates insecure and eventful experience of time for PES clients. In contrast to governing through freedom, the localised interpretation of activation policies represents the authoritarian and paternalistic side of neoliberal governance.
\end{abstract}

\section{Keywords}

Activation, actually existing neoliberalism, NEET, unemployment, workfare, young people

\section{Introduction}

Workfare - or labour market activation, in European terms - forms the core of employment policies in most OECD countries. Workfare policies are part and parcel of the shift to 'active' or neoliberal welfare states. This shift has also entailed changes in how unemployment and social risks in general are managed: governing unemployment means managing riskiness through government that puts the relationship to self under scrutiny. (Dean, 1995; 2002; Rose, 1999.) A substantial comparative policy analysis outlines how the individualising moral ethos of active citizenship and responsibility is played out in policy change (Betzel and Bothfeld, 2011; Kananen, 2014; Lindsay and Mailand, 2004; Van Berkel and Valkenburg, 2007). Political 
economy approaches analyse workfare as the (re)production of unfree, contingent, and unprotected labour (Adkins, 2012; Cooper, 2012; Peck, 2001).

However, how policies are made takes a different shape in the street-level practices of local welfare delivery (Lipsky, 1980). A growing body of ethnographic research addresses the problematics of workfare policy implementation and transformation in different national, legislative, and organizational contexts, focusing on how it is delivered (Brodkin and Marston, 2013; Van Berkel et al., 2016). However, less attention has been paid to how the relationship to self is put in action and how the active and responsibilized citizen is produced through streetlevel practice. Existing research has confirmed the neoliberal trope that case management enforces the imperative of self-improvement, self-governance, and active citizenship (Cruikshank, 1999; Darmon and Perez, 2010; Marston, 2005; McDonald and Marston, 2005), particularly for middle-class groups (Van Oort, 2015). On the other hand, some claim the opposite - programs directed at groups in marginal positions (occupationally disabled, racialized minorities, young people) produce passivity, frustration, and devaluation of skills (Holmqvist, 2010); shovel the participants into precarious work (Van Oort, 2015); trap clients between workfare schemes, training programs, and precarious work (Shildrick et al., 2012; Simmons et al., 2014); and control future orientations and behaviour (Intke-Hernandez and Holm, 2015; Mazouz 2015), without much attention to the relationship to self.

In this article, I contribute to the latter line of argument. I challenge the notion that managing the unemployed in street-level encounters is about producing self-governing, active citizens and managing the relationship to self. I draw from governmentality approaches (Dean, 1995; 2002) and ethnographies of governmentalities (Brady, 2011, 2014; Leppo and Perälä, 2017; McKee, 2009) to make two arguments. First, I argue that the street-level practice entails not only liberal ideas of self-governing individuals but also embodies authoritarian measures. What is governed is not the young people's selves but their time and behaviour. I further argue that not only the governing rationality contributes towards this end but also the 'messy, everyday realities' of street-level practice (McKee, 2009: 478-479), here interpreted as organizational and managerial demands and changes. Second, neoliberalism is increasingly understood as plural, localized, and existing side-by-side with competing rationalities (Brady, 2014; Lippert, 2014). Research is concerned with 'actually existing neoliberalism' and how neoliberalism as governance is enacted in practice (Peck et al., 2018; Wacquant, 2012). I concur with these analyses, but I also 
suggest that the authoritarian rationalities and measures should not be considered external but inherent to neoliberal governance and rationality.

The article is based on ethnographic research, including observations during client meetings, conducted at two local Public Employment Services (PES) offices in the Helsinki capital region of Finland. The focus is on the services directed at a special group: young people not in education or employment who lack formal post-compulsory vocational/professional qualifications. In the following, I contextualise the study in the Finnish policy framework, discuss the theoretical approaches, and describe the project, data, and methods and the PES in Finland. In the empirical section, I first discuss the sporadic appearance of the notion of self and responsibility in the data and then discuss how the focus shifted on controlling time and behaviour by addressing immediate time, futures, and temporal structures. To conclude, I discuss the empirical results and the relationship between liberal and illiberal rationalities.

\section{Situating street-level encounters: Workfare and changing social policy for young people in} Finland

The Finnish activation/workfare strategies are usually categorised to the social investment (SI) model, which promotes skills enhancement and further training as a means to (re)integrate a person into the labour market. Workfare models, on the other hand, force people to take any job available or participate in mandatory work activities. (Kildal, 2001; Theodore and Peck, 2001.) However, the Finnish labour market and social policy changes since the 1990s contain strong workfare elements, which have been consolidated in recent reforms (Adkins et al., 2017; Kananen, 2014; Keskitalo, 2008; Kildal, 2001). The main targets of workfare elements in Finnish social policy have been young people without formal post-compulsory education and the long-term unemployed. ${ }^{1}$

For these groups, access to social benefits (työmarkkinatuki, labour market subsidy) has become largely conditional. For young people without formal post-compulsory education, restrictions to access include a five-month waiting period from the start of unemployment, the obligation to apply for secondary education once a year, and the obligation to participate in any program, training, or job placement offered by the PES. They must also attend regular meetings, respond to job offers, keep their online $\mathrm{CV}$ updated and report on their online profile that they have accomplished all assigned tasks (Unemployment Security Act 1290/2012; The Social Insurance Institution of Finland, n.d.). Failing to fulfil these requirements can lead to sanctions and loss of 
unemployment benefits. Finland also has last resort, poverty relief (toimeentulotuki, income support). The increasing conditionality of the labour market subsidy have pushed young people to rely on this last resort poverty relief (Angelin et al., 2014).

In tandem with these restrictions, Finland has invested in policies and programs offering young people outside employment and education a multitude of courses, training and services with the aim of preventing social exclusion or integrating young people in education and work. A prime example is the Finnish policy program Youth Guarantee (n.d.), aimed at guaranteeing young people a study or work placement within three months after they had registered as unemployed with the PES. These investments have resulted in a network of governmental, municipal, private, and third-sector institutions involved in such employment and activation services (Haikkola et al., 2017; Brunila et al., 2016). The multi-sited service delivery results from decentralization policies and engages local authorities and street-level workers with the task of solving large-scale problems, such as youth transitions and employment (Adkins et al., 2017). Within this network, the role of the PES is hybrid and contradictory. It controls access to benefits, but also supports young people. It combines aspects of a referral agency, a service provider and a counselling office.

On the other hand, restrictions to benefits, the new programs and the related public discussion have come with strongly supportive and caring language. It stresses the need for participation and the risks involved in the perceived idleness but, at the same time, emphasises the state and other actors' concerns and good intentions for young people and their futures (Haikkola et al., 2017; Sukarieh and Tannock, 2015), mobilising a strong supportive and collective discourse about the need to help young people. However, despite the caring language, the forms of governance advocated by the neoliberal turn continued to embody control, behavioural demands, and exclusion of social protection.

\section{Theoretical perspectives: Ethnographies of governance and street-level organizations as policy-making sites}

Ethnographies of neoliberal governmentalities complement research on governmentalities of textual sources with ethnographic accounts (Brady, 2011, 2014; Leppo and Perälä, 2017). Governmentality as a broad approach (Miller and Rose, 2008) suggests that neoliberal governance should not be understood as a means of control but as offering solutions to particular problems of government. Unemployment is not only a state of being without a paid job but also 
a problem to be governed and a social identity that is seen to require moulding. The argument is that neoliberal governance is specific in that it seeks to govern through freedom, subjects by engaging subject in various practices, techniques, and rationalities of self-formation and selfgovernance. (Dean, 1995; McDonald and Marston, 2005; Miller and Rose, 2008.) However, Lemke (2001) highlights that Foucault suggested that understanding the genealogy of the 'Western subject' requires taking into account not only techniques of self but also techniques of domination. Further, Dean (2002) argues that neoliberal government contains authoritarian rationalities. In this article, I draw from this dimension, which outlines that liberal government relies on dividing the population into risky and dangerous groups and wielding paternalistic control. Liberal governing 'through freedom does not mean that individuals should be governed as if they were already capable of such autonomy' (Dean, 2002: 47).

While governmentality studies have mostly used textual or archival sources, ethnographies of governmentalities use ethnographic observation to investigate the multiple and fuzzy political rationalities and power relations that exist side by side in welfare state practices (Brady, 2014). Ethnographic approaches blur the distinction between discursive fields, within which the exercise of power is rationalised, and the sites and practices where power is enacted (Brady, 2014: 26-28). They help to identify the specific problem that welfare practices and reforms seek to govern. Further, to look into the 'messy empirical realities' (McKee, 2009, 478-479) brings this strand close to street-level bureaucracies (Lipsky, 1980) to look at the bureaucratic and institutional character of the client meetings. In this article, street-level organizations are considered as institutional locations in which particular forms of governing emerge, subjectivities are produced, and policy transformation is advanced.

\section{Research project, data collection, and methods}

This article draws from data collected in two local PES offices (TE-toimisto) in the Helsinki capital region in 2014-2015. The primary data for this article consists of ethnographic fieldwork in the PES office, consisting of observations of client meetings and several discussions with five of the six frontline workers in youth services in the two offices. ${ }^{2}$ During a period of five months, I visited the PES office and spoke with the frontline workers about their work, clients, and the public employment services generally. I also scheduled 30 observation sessions during client meetings (private client meetings are the main form of work in PES). On 20 occasions, the client came and agreed on the observation (e.g., during one day I had scheduled four sessions and none of the clients came). I took notes in my notebook of all discussions and interactions at the client 
meetings. The notes from all the ethnographic fieldwork in the PES were typed out into text files and the interviews recorded and transcribed. I refer to the client meeting observations by consecutive numbers $(\mathrm{O} 1, \mathrm{O} 2)$ and to all other field notes by date (e.g. April 2014). The extracts from the field notes shown here are shortened versions of the original typed field notes.

This dataset is complemented by a secondary dataset, which consists of formal interviews with the same frontline workers and document material (leaflets and pictures from the fieldwork, policy documents, steering documents, recommendations and rules, websites, and legislation). This material is not analysed here as such, but it was used to contextualise the analysis presented here in the organizational, managerial, and legislative context. For the research, I acquired permits from the regional PES administration and the clients. I informed all participants of the voluntarily participation, asked informally if I could join their meeting, and then asked for their written consent.

The data collection was part of a multi-sited and collaborative project, ${ }^{3}$ which addressed the question of youth employment within the network of governmental, municipal, private, and third-sector institutions described earlier (Haikkola et al., 2017; Brunila et al., 2016). From the larger dataset, this article focuses on the PES because, as a government body, they are legally responsible for implementing labour market policies and can use the threat of financial sanctions in their guidance work (Caswell et al., 2010). Frontline workers are not social workers but professionals with various educational backgrounds and typically have over 150 clients at a time. The PES works through pre-booked meetings every four weeks for the group studied here. These encounters are essentially bureaucratic (Lipsky, 1980) and structured with the aim of planning and updating the client's employment plan (Matarese and Caswell, 2017). The plan is formally a contract between the client and the PES, commonly interpreted as a form of governance in welfare delivery (Sulkunen, 2010).

The PES offices in this research project were chosen in cooperation with the PES administration from their offices in the Helsinki capital region. The chosen offices typically drew clients from lower socio-economic status neighbourhoods with a higher number of immigrants. The frontline officers considered the clientele more problematic than in predominantly middle-class areas of the capital region. My initial plan was to observe during a specific period of time to ensure a random selection of clients, but the frontline workers ended up choosing the clients. Thus, the clients in the observed meetings might be persons they wanted to present as either 'good 'or 
'bad' examples. However, a random selection is more likely, because we had to make an effort to find time slots that fit all our schedules. I asked for equal numbers of men and women (in the end, 12 women and eight men were included). The clients I eventually came to observe were a heterogeneous group with various concerns and aspirations (based on my observations during the meetings). They did not fit the public perception of vulnerable and risky young people advocated by Finnish policy and public discourse (Brunila et al., 2016). They included prospective students who had failed to get into their preferred educational programme, who were looking to continue their unfinished programmes, who wanted a career change or study advice, or who had had problems in the past but were now looking for new directions. What united them was the lack of formal vocational/professional qualifications and the consequent placement into the 'second stream' at PES, a service stream intended for young clients who were perceived to be in need of skills enhancement before entering the labour market.

'Streaming' clients based on their perceived abilities and service needs was a newly introduced organisational reform to make service delivery more effective (Caswell et al. 2010; Haikkola et al, 2107).

The ethnographic data was analysed thematically following Layder's (1998: 52-60) process of coding and typologising. First, the materials were pre-coded with general notes and then systematically coded using concrete and theoretical codes. After the initial phase, the analyses alternated between analysis and theorization (Swedberg, 2016). Following ethnographies of neoliberal governmentalities (Brady, 2014), the guiding question of the analysis was, what is governed in the street-level practice? This identified the two key themes of the data - the sporadic appearance of the notion of self and responsibility and the shift to a focus on controlling time and behaviour. In the following, the analysis is presented in this order.

\section{Playing the game: Sporadic appearance of responsibilized subjectivities in street-level practice}

It is often maintained that the national context shapes activation policies. However, contrary tendencies also exist, as the behaviour and attitudinal skills, such as responsibility, activity, motivation and lowering expectations, advocated in street-level services are very similar across OECD countries (Darmon and Perez, 2010: 86-87; Marston, 2005). Such themes were circulated in my interview data as well. At the early stages of my fieldwork, I chatted with Minna, a long-time employee of PES. She explained: 
Well, if there is a course coming up, we discuss, and I try to push the client. The initial sorting [into the 'streams'] should carefully consider whether the client is suitable for the labour market or in need of skills enhancement. And this should ideally be from the perspective of the labour market, not the clients' own opinion. [...] So we check the clients' study and work plans, motivate and activate them, and pressure them to do something. And we meet in regular intervals, if needed, because not everything always goes as planned (Field notes, April 2014).

She continued: "[I]deally, clients should be activated to independently familiarise themselves with the different service options available between our meetings". Similarly, Krista, another frontline worker, explained how one of her clients had not met the expectations of a selfdirecting client because he had failed to arrange a placement for himself. Krista had had to take the initiative usually expected from the client:

Krista said that she had called the NGO (which runs the workshop activities) herself, although usually her aim is that the clients contact the service provider themselves, that they are actively communicating, that they are self-directing (Field notes, April 2014).

This is how the frontline workers verbalized how motivation, activity, and self-direction are the personal qualities that the young clients should possess. This way of talking emphasised that the clients should acknowledge their difficult situation and focus on solving it through investing in such qualities and also in the services offered by PES and locate their success in their own efforts. Although other, more supportive and caring rationalities existed (as Krista above helped her client), this discourse suggests that the liberal rationality exists in the PES services, acting upon the relationship to self.

Research on job seekers (mainly on adult clients) shows that the subjectivities offered are both accepted and resisted (Caswell et al., 2010; Darmon and Perez, 2010; McDonald and Marston 2005; Van Oort, 2015). In this data, the young clients acted in ways that suggested that they had accepted and internalised such expectations. In the beginning of the client meetings, the clients usually quickly commented upon their efforts, claiming their activity and responsibility: 
The client arrives. He is polite and attentive. He begins by what reminds me of assertion: explains that 'I have done this and that, contacted them, I have applied this and that'. When Minna suggests a course, he quickly comments that he has already checked it with another career counsellor (O4, April 2014).

The young woman wants to have an apprenticeship placement to become a practical nurse. She repeats that she has 'applied and applied', says that for 20 openings there are 400 applicants, and that's why it is so difficult. She repeats she does not understand why it is so hard to get a placement, she had such good reviews from her previous employer (O13, May 2014).

In the course of the meetings, the accepting orientation seemed to continue. The young clients did not speak much, but were nodding, answering shortly, and only occasionally asking short, technical questions:

We are looking at stuff about apprenticeships online. The client is watching. He remains silent. Krista urges him to 'contact employers' to possibly get an apprenticeship placement. She continues to say that she will now 'type in everything on the computer' and advises the client to 'just ask if there is something'. The client answers 'mmmm'. Krista types, the client is staring. This takes some time; we are all quiet (O5 Field notes, April 2014).

Few challenged the case workers' suggestions, at least not verbally. Thus, the young clients' assertiveness and attentiveness can be interpreted as acceptance of their role as an active, motivated, and persistent jobseeker and as an example of a successful production of a moral relationship to self. However, interpreting clients' actions through the institutional context and the materiality of the encounters, the clients were mostly adapting to a situation and status in which they did not really have any choice and were not really accepting the active subject position.

First, the banal materiality of the encounters shaped clients' behaviour. There was virtually no space for talking during the meetings. PES requires extensive documentation of client work. The documentation into the PES database took considerable amounts of time, and while the frontline workers were typing, the client often sat waiting for the meeting to continue. Second, as shown 
by Matarese and Caswell (2017), the standardised, bureaucratic structure of the meeting that aims at going through the employment plan does not always allow the client a voice. Meetings consisted of checking what the client had accomplished since the last meeting and suggesting similar or alternative measures, then wrapping up the meeting by going through updates to the plan. This did not allow for questions, resistance, or discussion. Third, the workfare elements in the legislation on the social security of young, unemployed individuals without formal secondary education (described in the second section of this article) outlines that their access to monetary benefits depends on multiple behavioural obligations which include actively taking care of a large number of requirements and reporting on their efforts (The Social Insurance Institution of Finland, n.d.).

Second, children and young people's agency and resistance is not always expressed formally through voicing concerns but through their actions and bodies (Kallio and Häkli, 2011). Research on young people in workfare services has observed that young people resist by dropping out, not attending, or cancelling courses, as well as with general frustration and anger (Lähteenmaa, 2013; Shildrick et al., 2012; Simmons et al., 2014). My research has similar findings. During the silent periods in the meeting, the did not just sit waiting but also fidgeted on the chairs, fiddled with their phones, gazed absently at the many posters and leaflets about courses and programs hung on the office walls, and occasionally gave deep sighs as signs of boredom or unease. Some of their actions were more radical. Some rescheduled their appointments strategically in order to avoid meetings while maintaining benefits eligibility, some just did not come to their meetings (which resulted in 14 no-shows during my data collection), or stopped attending the courses they were assigned to, losing their benefits. Jessika, another frontline worker, explains:

"They churn here. They register as clients online, I send the invitation to the meeting, they never come, and then they register as clients again. But we can't say no to them, we have to give them appointments (Field notes, September 2015).

Interpretations about resistance and strategic action raise the issue of responsibility and moral worth. Simmons and colleagues $(2014,178)$ observed that benefit conditionality and the number of regulations create conditions in which young clients come to be construed as irresponsible and useless, not the responsible and entrepreneurial subjects that neoliberalism seeks to construct. This further justifies controlling measures. Above, Jessika remains frustrated but 
neutral in her description of the clients' behaviour, but the clients' actions were also interpreted as reckless and irresponsible:

Minna says she wants to talk to me about the clients I was observing previously. I had made a vague comment that to me the clients seemed 'normal' and active. Now Minna sounds a bit ironic when she says that although 'we' booked the clients to the course, many of them did not go. Like the one I pointed out as 'active and participating' did not show up and did not send any message (Field notes, June 2014).

Thus, instead of a contradiction between production, internalising, or resisting the active self, the meetings seemed like a game in which the young clients responded to the expectations of the PES office rules, and the PES responded by evaluating their actions. Often they failed, lost benefits, and accumulated a waiting period/work obligation to regain their benefits, pushing them to rely on means-tested income support, as observed by Angelin and colleagues (2014). At the same time, the frontline workers were occupied in training their clients to act according to the PES rules and be accurate, compliant, and punctual. Here the active and responsible orientation of a morally worthy unemployed person that the clients were required to exhibit was not supposed to be directed towards their futures or their selves as such but towards acting correctly within the system. Overall, the notion of the active self and a responsibilized subject was sporadically present and vaguely mobilised in everyday practices of the PES.

\section{Governing time and behaviour in street-level encounters}

I now turn to look into what instead came to be governed in the meetings. The ethnographic data, particularly from the actual client meetings, reveals that what is governed in the meetings shifts from selves to governing of time and behaviour. Here I discuss this in relation to the immediate time, futures, temporal structures, and experience of time.

From the frontline workers' perspective, the ideal activated and self-directing client often failed to show up in the services, mostly because the clients' efforts for education or work did not lead anywhere. Here the concern for participation, getting the clients 'somewhere' (as Minna explains in the quote in the previous section) overruled the concern for independent and active self-management, clients' motivations and goals, or the relationship to self. This was accentuated by the fact that not only clients but also the frontline workers spoke very little 
during the meetings, and the sparse talk mostly concerned the practicalities. Instead of working explicitly on the subjectivities of their clients through motivational or morally charged talk, the service providers began to push and pressure the clients to 'do something', like in the meeting between Krista and a young woman:

A young woman comes to the meeting. She is pregnant, and her maternity leave will start in three months. She has completed high school and applied for a bachelor's degree in nursing at a university for applied sciences to become a certified nurse. Krista and the young woman talk briefly about her possible studies and the possibility of unpaid work experiment.

Quite suddenly, Krista suggests another activation measure, the 'youth workshop'. There are two choices, one in the field of 'café and arts and crafts' and another where 'the participants can decide on the content'. The client does not really acknowledge these suggestions and merely nods.

Krista concludes by encouraging the client to 'apply' for basically anything: work trials, workshops, other sectors. They do not discuss her nursing studies. They finish, and the young woman leaves. Krista and I discuss, and Krista says this was mostly about finding the client 'something to do' before her maternity leave (O1, April 2014).

While Krista's many encouragements to 'apply' can be read as motivation for active orientation, being active also takes another shape. In the brief encounter, the young woman's primary aim, applying to become a nurse, received no attention. Instead, Krista's focus was on the time between the meeting and the start of the maternity leave within three months. Krista suggested multiple measures, none of which seemed to relate to the client's future plans and did not deal with the problematics of self-governance. From the organization's perspective, it was not conceivable that the three months before the maternity leave should be spent without an organised activity. The newly introduced structure of the workshop programme (a rehabilitative youth program, which has been running since the early 1990s) that allowed new participants to start at any time supported Krista's time-filling aim. The focus of the meeting was on finding the young woman an activity. 
In the meetings, being without controlled activity left the clients technically inactive and, therefore, in the perceived need of a course, programme, or other measure. This happened not only in relation to personal circumstances, as with the pregnant young woman, but also more generally in relation to the Finnish school year, which consists of two semesters. Most educational programmes within the regular secondary and tertiary sectors begin in August or January. In case the applicant had not entered a programme, the time spent waiting for the next application round needed to be filled with an activity. Clients were directed to search for unpaid work placements and enrolled in short career-counselling courses provided by the adult education and labour market training sector, from which PES contracts activation services:

The young man is a professional athlete training with the Finnish team and aspires to be a sports instructor/PE teacher. No educational program in the field is available right now, and he had not been accepted when he last applied, so Minna suggests that he attend a 30-day career counselling course in 'sales and services'. The course is designed for familiarising oneself with a particular profession. This will enable him to get unemployment benefits during the 30 days +9 euro daily supplement. He says he is not interested in sales, but sports, and tries to decline. Minna registers him for the course, without his agreement. He seems frustrated and is concerned for his sports practice, but sighs: "That's it, then" (O18, April 2014).

Mazouz (2015) has shown how young people's personal goals and futures are controlled in the name of morally evaluating the client. The example above suggests similar processes. The suggested course will not lead anywhere and might even distract the client from his chosen career and future and potentially challenge his sports career. While the client shows motivation to his own goals, this is suppressed, and the client is required to show motivation towards a measure and future offered by PES. No motivational speech (except the access to benefits) or moral evaluation is verbalized in the encounter. The focus is on straightforwardly assigning courses in order to 'do something'. This also means that instead of striving for skills enhancement, as in SI models, attendance has an instrumental and technical aim. In this context, no responsibility to self can solve these situations or move the person into the non-risky group without a need for control or measures. The only personal strategy involved is to act correctly within the system, accept the time-filling aims, and hope for an exit through paid work or educational placement providing qualifications. 
Workfare policies are based on the moral sanctioning of unemployment. On the other hand, Adkins (2012: 634-636) claims that they also rework the materiality of unemployment and transform it from a structural position of exclusion and passivity into an eventful and lively state (634-636). The temporal structure of unemployment takes the shape of an event, which means that unemployment becomes a series of events happening in unpredictable ways. Contemporary youth policies that focus on youth employability and govern riskiness through participation and forms of activation (Brunila et al., 2016; France, 2016) share this element. They rework the materiality of youth unemployment, so-called NEET ${ }^{4}$ status, and the youth transition period from school to work into an eventful state. Courses, trainings, and job placements happen unexpectedly with a specific aim to fill time and provide money.

Social policies and public discourse often advocate that this approach protects young people and that, for young people, doing 'something is better than doing nothing (Simmons et al., 2014: 219). This discourse is justified by the notion that while not participating is morally sanctioned, the more pressing concern is that it can lead to a risk of permanent social exclusion. This manifested in this research in how young people's aims for formal qualifications, such as becoming a sports instructor/PE teacher or practical nurse (as I witnessed during the meetings), were rarely discussed in the meetings, especially if the option to apply was not within the time limits of the PES office and its guidelines. The timespan of the meetings was short-term, focusing on how immediate time, not futures as such, become organised. The young clients' long-term goals and aspirations were often overlooked in the urgency to 'activate' them. This perspective shifts the focus on reworking subjectivities and relation to self to reworking temporalities and materiality and suggests that the making of subjectivities occurs by taking time and behaviour, not self, under control. The problems of government shift to excess, loose, or unactivated time.

The organizational contexts also steer the meeting towards such time-controlling activities, making the frontline workers' actions understandable. The frontline workers can use discretion in their decisions and counter this tendency, but the recent changes in the organizational management sets limits to discretion. Shortly before the data collection began, a reformed performance target scheme for the PES workers was introduced, which provided individual performance targets for frontline workers. The new targets involved, for example, numbers of job offers sent to clients, the number of clients' CVs inserted into an online eservice maintained 
by PES and the proportion of clients in activation measures, called the 'activation rate'. The new performance target scheme then demanded similar active and compliant attitudes from the frontline workers as from the unemployed clients and directed the frontline workers to send the clients to even more courses and measures to fill the activation rate and meet their targets. The performance targets geared the frontline workers to act towards the targets and the system, not towards the client, perpetuating the practice of taking control of clients' time.

Such statistical goals and the ambiguous role both as a supporter and a controller presents a moral dilemma for frontline workers and often conflicts with how they themselves perceive their work, as Mazouz (2015) has also shown. In this data, frontline workers dealt with this in varying ways:

Hannele says: 'We motivate someone to attend a youth workshop, then we find an old breach and benefits are cut.' She continues that the rules of the unemployment benefits are 'crazy' for young people. In her opinion, there should be no benefits for young people without education but instead no sanctions and always a measure available. Participation would always channel the benefits (Field notes, April 2014).

Above, Hannele states that the complicated rules do not motivate or support young clients. While the frontline workers also used the moralising discourse of clients' welfare dependency to justify the measures, in Hannele's street-level interpretation, the moral underpinnings are lost. Her concern is both caring, practical, and instrumental, shaped within the routinized service delivery context of the messy empirical realities of street-level practice. She seems to suggest an opposite to a universal basic income, something similar to a 'universal basic activity', a model in which social protection would always depend on engaging in organised activities. She provides no other explanation for the need of a course or a training than making the system more understandable. The basic tenets for social citizenship as a status that itself guarantees basic social protections is turned upside down. ${ }^{5}$ Such a vision of youth services and social protection that stresses general participation over individual goals consolidates control over the clients' time and strengthens the eventfulness of the time structure (Adkins, 2012). 


\section{Discussion and conclusion}

In this article, I have considered PES offices as institutional locations in which particular forms of governance emerge, subjectivities are produced, and policy transformation advanced. Dean (1995: 572-577) argued that in workfare states, power operates on the inside, as the unemployed are encouraged to establish a particular relation to self and become active subjects and morally worthy citizens through various practices, techniques, and rationalities of self-governance. His ideas have been used to explore the street-level practice as a site for the production of, but also resistance to, this rationality (Caswell et al., 2010; Cruikshank, 1999; Darmon and Perez, 2010; McDonald and Marston, 2005).

In this article, I show an opposite tendency. I have argued that the frontline workers did rely upon and reproduce the discourse of self-sufficient, responsible, and active citizens, but only sporadically. This sometimes extended to the actual meetings as they topped their otherwise quite silent and straightforward encounters with their clients with encouragements to 'be active' and 'apply'. Instead, I witnessed that another rationality overruled the concern for an active self. In the meetings, it was not young people's motivations or subjectivities or the relation to self that came under control but rather their use of time and behaviour and their perceived inactivity. Time outside supervised or government-sponsored activities was considered inactive, and this inactivity needed to be governed and managed by assigning young people to any available service. The actual, street-level practice of service delivery was mainly aimed at exerting control over the young client's future plans, use of time, and actions, with a particularly short-term focus. Loose or excess time became the focus of governance. Case work creates and shapes subjectivities, and in the local service delivery, this happens by controlling time, not self.

I argue that on top of shaping subjectivities, activation measures also shape young people's time structures, creating different experiences and ownership of time for different societal groups. It has been show that social protection is dualising between the age groups as young people are increasingly covered by the last resort poverty relief (Angelin et al., 2014). However, dualising occurs also within the youth group (Chevalier and Palier, 2014). The street-level practice that takes young people's goals, time, and behaviour under control deepens these divisions, producing different subjectivities and creating different experiences of time during the period of transition from school to secondary education and work. Those young people on straightforward paths from school to work who avoid out-of-work periods and NEET status do not become 
subjects to such practice and subject-making. The 'risky' young people, on the other hand, are increasingly subject to governance which emphasises time as a central element.

Thus, governing through freedom, which is considered to be the overruling form of governing in neoliberal societies, does not apply to all societal groups nor all groups of unemployed. In his work on the large-scale government subsidised employment program for citizens classified as occupationally disabled, Holmqvist (2010) observed that the project produced passivity and frustration. The participants were not considered to possess the autonomy required from proper neoliberal subjects (Dean 2002: 47), but it was also hard to interpret the program to be about the production of such autonomous subjects. Empowerment remained merely a trope for justifying the program itself (Holmqvist, 2010). Van Oort (2015) makes a similar observation about workfare programs for marginalised groups (working class and racialized minorities). She interprets them as process-driven, aimed at controlling the behaviour of clients and churning them into the lower end of the labour market with little concern for self.

Drawing from Dean's (2002) argument that neoliberal governing always contains authoritarian mentalities and practices, I argue that the localised interpretation of activation policies reported in this article represents this authoritarian and paternalistic side. Activation became an end in itself and transformed into a very literal version of itself, an act of doing something. Guidance mostly regulated action within a complex system of policy guidelines and managerial and legislative demands. On the other hand, it has been shown that workfare consists of a fundamental contradiction - the rationality to take responsibility and the behavioural demands to be compliant (Crespo Suarez and Serrano Pasqual, 2007; Peck, 2001). What is new here, thus, is not the controlling dimension but the total disappearance of any attention to the relationship to self or the making of responsibilized subjects. My ethnographic data from the client encounters speaks of a disappearance of both self and the imperative for constant self-invention and selfgovernance.

However, these outcomes of activation policy delivery did not come solely from a controlling rationality operating in the encounters between the frontline worker and the young clients. They were also shaped by the messy empirical realities of street-level practice - the overload of clients per frontline worker; managerial reforms, such as performance targets and the new organizational categories of service streams; the detailed guidelines for delivery service for 
young clients; workfare legislations; and also the decentralized, dispersed, course-based provision of service (Haikkola et al., 2017).

In her work on ethnographies of neoliberal governmentalities, Brady (2011, 2014; also Lippert, 2014) proposes that ethnographic work helps to make visible the existence of competing or marginalized political rationalities. Ethnography exposes that the power structures are not unified and help to distinguish how neoliberal and other rationalities are played out in localised practices. Her work is part of a broader attempt to analyse the plurality of actually existing neoliberalism (Peck et al., 2018; Wacquant, 2012). While I witnessed rationalities that can be seen as illiberal or relating to earlier modes of governance, I propose that the authoritarian elements discussed in this article are not manifestations of different rationalities of governance or external to neoliberal rationality but a key element in it and its operations. They can be interpreted as a continuation, not a discontinuation, from previous forms of controlling the disadvantaged by controlling access to means of supporting oneself (Cooper 2012; Nenonen, 2006). In contrast to the textual sources (policy documents, archival sources), they come into being particularly in the local practices of various sites of governance. Ethnographic research on restructuring welfare states allows a careful examination of how societal groups, such as young people or youth as a life stage, become understood to be in need of control, remedy, and moulding and subjected to authoritarian power.

\section{Funding}

This article draws from the research project Migrant Youth Employment - Politics of Recognition and the Boundaries of Belonging, supported by the Kone Foundation, the Emil Aaltonen Foundation, and the University of Helsinki three-year research grants.

\section{Acknowledgements}

I would like to thank the four anonymous reviewers for their extremely helpful comments on the earlier drafts of this article

\section{Conflict of interest}

This article reports no conflicts of interest. 


\section{Notes}

1 The policy changes in the beginning of 2018 extended elements of conditionality for groups in working life, marking a new, significant shift in the Finnish social protection system.

2 One frontline worker did not agree to observations or interviews.

3 Assistant professor Lena Näre, with postdoctoral researcher Elina Paju and doctoral candidate Daria Krivonos.

4 A statistical group, which refers to Not in Education, Employment or Training (see OECD, 2018).

5 A committee on the reform of social security for young people, consisting of prominent researchers in Finland, proposed a similar scheme (Hiilamo et al., 2017)

\section{References}

Adkins L (2012) Out of work or out of time? Rethinking labor after the financial crisis. South Atlantic Quarterly 111(4): 621-641.

Adkins L, Kortesoja M, Mannevuo M, and Ylöstalo H (2017) Experimenting with price:

Crafting the new social contract in Finland. Critical Sociology. Epub ahead of print 23

November 2017. DOI: 10.1177/0896920517740614.

Angelin A, Kauppinen T, Lorenzen T, Bäckman O, Moisio P, Dahl E, and Salonen T (2014) Have Nordic welfare regimes adapted to changes in transitions to adulthood? Unemployment Insurance and social assistance among young people in the Nordic countries. In: Antonucci L, Hamilton M, and Roberts S (eds) Young People and Social Policy in Europe. Houndmills: Palgrave MacMillan, pp. 169-188.

Betzelt S and Bothfeld S (eds) (2011) Activation and Labour Market Reforms in Europe: Challenges to Social Citizenship. Houndmills: Palgrave Macmillan.

Brady M (2011) Researching governmentalities through ethnography: The case of reforms and programs for single parents. Critical Social Policy 5(3): 265-283. DOI:

10.1080/19460171.2011.606300.

Brady M (2014) Ethnographies of neoliberal governmentalities: From the neoliberal apparatus to neoliberalism and governmental assemblages. Foucault Studies 18: 11-33.

Brodkin EZ and Marston G (eds) (2013) Work and the Welfare State: Street-Level Organizations and Workfare Politics. Washington: Georgetown University Press. 
Brunila K, Ikävalko E, Kurki T, Mertanen K, and Mikkola A (2016) Revisiting the vulnerability ethos in cross-sectoral transition policies and practices for young people in the era of marketization of education. Research in Comparative \& International Education 11(1): 69-79. DOI: $10.1177 / 1745499916631060$.

Caswell D, Marston G, and Larsen JE (2010) Unemployed citizen or 'at risk' client? Classification systems and employment services in Denmark and Australia. Critical Social Policy 30(3): 384-404. DOI: 10.1177/0261018310367674.

Chevalier T and Palier B (2014) The dualisation of social policies towards young people in France: Between familism and activation. In: Antonucci L, Hamilton M, and Roberts S (eds) Young People and Social Policy in Europe. Houndmills: Palgrave MacMillan, pp. 189-209.

Cooper M (2012) Workfare, familyfare, godfare: Transforming contingency into necessity. The South Atlantic Quarterly 111(4): 643-661. DOI: 10.1215/00382876-1724120.

Crespo Suárez E and Serrano Pasqual A (2007) Political production of individualised subjects in the paradoxical discourse of the EU institutions. In Van Berkel R and Valkenburg B (eds) Making It Personal. Individualising Activation in the EU. Bristol: The Policy Press, pp. 107125.

Cruishank B (1999) The Will to Empower: Democratic Citizens and Other Subjects. Ithaca: Cornell University Press.

Darmon I and Perez C (2010) 'Conduct of conduct' or the shaping of 'adequate dispositions'? Labour market and career guidance in four European countries. Critical Social Policy 31(1): 77101. DOI: $10.1177 / 0261018310385440$.

Dean M (1995) Governing the unemployed self in an active society. Economy and Society 24(4): 559-583. DOI: 10.1080/03085149500000025.

Dean M (2002) Liberal government and authoritarianism. Economy and Society 31(1): 37-61. DOI: $10.1080 / 03085140120109240$. 
France A (2016) Understanding Youth in the Global Economic Crisis. Chicago: The University of Chicago Press.

Haikkola L, Näre L, and Lähteenmaa J (2017) Tunnistamisen institutionaaliset kontekstit: Nuoret työttömät aktivointitoimenpiteissä (The institutional contexts of recognition: Young people's experiences of activation measures). In: Aaltonen S and Kivijärvi A (eds) Nuoret aikuiset hyvinvointipalvelujen käyttäjinä ja kohteina. Helsinki: Nuorisotutkimusseura, pp. 5378.

Hiilamo H, Määttä A, Koskevuo K, Pyykkönen J, Räsänen T, and Aaltonen S (2017) Nuorten osallisuuden edistäminen: Selvitysmiehen raportti (Promoting the participation of young people: Report by a committee on reform of youth social security). Available at: http://nuorisotakuu.fi/materiaalit-ja-ohjeet (accessed 15 December 2017).

Holmqvist M (2010) The 'active welfare state' and its consequences. European Societies 12(2): 209-230. DOI: 10.1080/14616690903388960.

Intke-Hernandez M and Holm G (2015) Migrant stay-at-home mothers learning to eat and live the Finnish way. Nordic Journal of Migration Research 5(2): 75-82. DOI: 10.1515/njmr-20150012 .

Kallio KP and Häkli J (2011) Tracing children's politics. Political Geography 30(2): 99-109.

Kananen J (2014) The Nordic Welfare State in Three Eras: From Emancipation to Discipline. London: Routledge.

Keskitalo E (2008) Balancing Social Citizenship and New Paternalism: Finnish Activation Policy and Street-Level Practice in a Comparative Perspective. Helsinki: Stakes.

Kildal N (2001) Workfare Tendencies in Scandinavian Welfare Policies. Geneva: ILO.

Layder D (1998) Sociological Practice: Linking Theory and Social Research. London: Sage. 
Lemke T (2001) 'The birth of biopolitics': Michel Foucault's lecture at the Collège de France on neo-liberal governmentality. Economy and Society 30(2): 190-207.

Leppo A and Perälä R (2017) Remains of care: Opioid substitution treatment in the post-welfare state. Sociology of Health and Illness 39(6): 959-978. DOI: 10.1111/1467-9566.12550.

Lindsay C and Mailand M (2004) Different routes, common directions? Activation policies for young people in Denmark and the UK. International Journal of Social Welfare 13(3): 195-207. DOI:10.1111/j.1369-6866.2004.00314.x.

Lippert R (2014) Neoliberalism, police, and the governance of little urban things. Foucault Studies 18: 49-65.

Lipsky M (1980) Street-Level Bureaucracy: Dilemmas of the Individual in Public Services. New York: Russell Sage Foundation.

Lähteenmaa J (2013) 'Agency vs. structure'. A view of youth unemployment during current recession in Finland. In Helve $\mathrm{H}$ and Evans $\mathrm{K}$ (eds) Youth and work transitions in changing social landscapes. London: Tufnell Press, pp. 68-81.

McDonald C and Marston G (2005) Workfare as welfare: Governing unemployment in the advanced liberal state. Critical Social Policy 25(3): 374-401. DOI:

$10.1177 / 0261018305054077$.

McKee K (2009) Post-Foucauldian governmentality: What does it offer critical social policy analysis? Critical Social Policy 29(3): 465-486. DOI: 10.1177/0261018309105180.

Marston G (2005) The active subjects of welfare reform: A street-level comparison of employment services in Australia and Denmark. Social Work \& Society 3(2): 141-157.

Matarese M and Caswell D (2018) I'm gonna ask you about yourself, so I can put it on paper. Analysing Street-level bureaucracy through form-related talk in social work. The British Journal of Social Work 48(3): 714-733. DOI: 10.1093/bjsw/bcx041. 
Mazouz S (2015) Profiling of job seekers: Counseling of youths at an employment center. In: Fassin D et al. (eds) At the Heart of the State: The Moral World of Institutions. London: Pluto Press, pp. 225-254.

Miller P and Rose P (2008) Governing the Present: Administering Economic, Social and Personal Life. Oxford: Polity.

Nenonen M (2006) Lapiolinjalla: Työttömät pakkotöissä 1948-1971 (Forced public works in Finland 1948-1971). Jyväskylä: Atena.

OECD (2018) Youth not in employment, education or training (NEET) (indicator). DOI: 10.1787/72d1033a-en (accessed 11 January 2018).

Peck J (2001) Workfare States. New York and London: The Guildford Press.

Peck J, Theodore N, and Brenner N (2018) Actually existing neoliberalism. In: Cahill D, Konings M, Cooper M, and Primrose D (eds) The Sage Handbook of Neoliberalism. London: SAGE, pp. 3-15.

Rose N (1999) Powers of Freedom: Reframing Political Thought. Cambridge: Cambridge University Press.

Shildrick T, MacDonald R, Webster C, and Garthwaite K (2012) Poverty and Insecurity: Life in Low-Pay, No-Pay Britain. Bristol: Policy Press.

Simmons R, Thompson R, and Russell L (2014) Education, Work and Social Change: Young People and Marginalization in Post-Industrial Britain. New York: Palgrave Macmillan.

Suárez EC and Pasqual AS (2007) Political production of individualised subjects in the paradoxical discourse of the EU institutions. In: Van Berkel R and Valkenburg B (eds) Making It Personal: Individualising Activation in the EU. Bristol: The Policy Press, pp. 107-125.

Sukarieh M and Tannock S (2015) Youth Rising? The Politics of Youth in the Global Economy. London: Routledge. 
Sulkunen P (2010) Agency and power: The contractual illusion. European Journal of Cultural Studies 13(4): 495-510. DOI: 10.1177/1367549410377156.

Swedberg R (2016) Before theory comes theorizing or how to make social science more interesting. The British Journal of Sociology 67(1): 5-22.

Theodore N and Peck J (2001) Searching for best practice in welfare-to-work: The means, the method and the message. Policy \& Politics 29(1): 81-94.

The Social Insurance Institution of Finland (n.d.) Restrictions for applicants under 25 years of age and persons without vocational training. Available at https://goo.gl/zxyc53 (accessed 15 December 2017).

Unemployment Security Act 1290/2012. Available at https://goo.gl/gAh5Qy (accessed 11 May 2018).

Van Berkel R and Walkenburg B (eds) (2007) Making it Personal: Individualising Activation Services in the EU. Bristol: The Policy Press.

Van Berkel R, Caswell D, Kupka P, and Larsen F (eds) (2016) Frontline Delivery of Welfare-toWork Policies in Europe: Activating the Unemployed. New York: Routledge.

Van Oort M (2015) Making the neoliberal precariat: Two faces of job searching in Minneapolis. Ethnography 16(1): 74-94. DOI: 10.1177/1466138113506636.

Wacquant L (2012) Three steps to a historical anthropology of actually existing neoliberalism. Social Anthropology 20(1): 66-79. DOI: 10.1111/j.1469-8676.2011.00189.x.

Youth Guarantee (n.d.) Available at http://nuorisotakuu.fi/etusivu (accessed 15 December 2017). 


\section{Author biography}

Lotta Haikkola is a postdoctoral research at the Finnish Youth Research Network. Her current research focuses on young workers, changing labour market and activation policy. Previously, she has conducted research on the second generation, identities and destigmatization strategies, and young people's transnational relations. 